\title{
Gen Z: Exploring Service Learning Projects in Managerial Accounting
}

\author{
Tracie Edmond \\ University of the Incarnate Word \\ Trish Driskill \\ University of the Incarnate Word
}

Service learning projects capitalize on the unique characteristics of Gen $Z$ students and meet the requirements of the American Institute of Certified Public Accountants' (AICPA) core competencies. This project not only increased students' soft skills, making them more marketable to future employers, but also made a difference in the lives of the people served. Participants mastered managerial accounting topics through hands-on experiences that are often considered complex to grasp, which instilled inspiration and creativity. The findings of this paper may be useful to educators to increase student interest, as well as develop the AICPA's core competencies in future accountants.

Keywords: Service Learning, Gen Z, Accounting, Charity, Non-profit.

\section{INTRODUCTION}

Owing to a declining number of accounting majors in recent years, accounting programs are examining methods to increase student interest and further develop individuals' skillsets before entrance into the accounting profession. Active learning has gained interest within the accounting field, as research demonstrates that this form of learning contributes to an individual's ability to transfer knowledge from the textbook to the real-world (Accounting Education Change Commission [AECC], 1990; Bonner, 1999; Davidson, 2017; Healy \& McCutcheon, 2008; Yardley-Matwiejczuk, 1997).

As accounting professors, we had two goals for a service learning project. The first objective was the engagement of our Gen Z students, and the second goal was the incorporation of the American Institute of Certified Public Accountants' (AICPA) core competencies to increase students' skillsets in meeting the needs of the profession. Therefore, a unique tri-sector service learning project was adopted that utilized the knowledge of the Gen Z characteristics to help instill the AICPA's core competencies in our students.

A tri-sector project is one that involves collaboration between the education sector, the for-profit sector, and the non-profit sector. Because accountants are needed in every sector, this project exposed the students to the differences in the sectors and allowed the students to see how managerial accounting principles are utilized in every sector. By applying, the knowledge learned about the Gen $\mathrm{Z}$ characteristics into the tri-sector service learning project, students became more engaged in the project, made a great impact on their community, and increased their skillsets required by future employers. 


\section{GEN Z AND SERVICE LEARNING}

A new generation has entered the classroom and will be entering the workforce, Gen $Z$. Understanding what makes this generation distinctive will help professors fully engage Gen $\mathrm{Z}$ students in the classroom, help increase their interest in the accounting profession, and better prepare them for the workforce. Based on the research, Gen $\mathrm{Z}$ individuals develop six unique characteristics: phigital, hypercustom/do it yourself (DIY), realistic, fear of missing out, weconomists, and driven (Stillman \& Stillman, 2017).

\section{Phigital}

Gen $\mathrm{Z}$ is the first generation born into a world where every physical aspect, people, and places, has a digital component. As a result, $91 \%$ of Gen $Z$ state that a company's technological sophistication would affect their decision to work there (Stillman \& Stillman, 2017). In fact, if a company does not have a dynamic presence online, to Gen Z, that company does not exist. Because Gen Z has the phigital characteristic, educators should use tools like Skype, FaceTime, Google Hangouts, and Job Snap. For Gen $\mathrm{Z}$ students, establishing real-world experiences is important, such as internships and service learning projects that incorporate both physical and digital components.

\section{Hyper-Custom \& DIY}

Gen $\mathrm{Z}$ has always worked hard at identifying and customizing their own brand for the world to know. According to Stillman and Stillman (2017), 56\% of Gen Z would rather write their own job description than be given a generic one and $62 \%$ of Gen $\mathrm{Z}$ would rather customize their own career plan than have the organization lay one out for them. Gen Z is the DIY generation because they grew up with tools, such as YouTube that can teach them how to do just about anything. Some examples of ways that professors can capitalize on these two characteristics are to create training and teaching modules that combine selfteaching tools with face-to-face mentoring and coaching and provide opportunities for students to customize their projects.

\section{Realistic}

Gen $\mathrm{Z}$ believes to survive and thrive; one needs to be realistic about what it will take to be successful in the marketplace and in life. This generation is more hesitant about going to college and more skeptical about the value of the college degree. This skepticism may be because of the Bureau of Labor Statistics' research that stated that 1 in 8 recent college graduates are unemployed, and half of recent graduates with employment hold jobs that do not require a college degree (Stillman \& Stillman, 2017). While this is beginning to change with the current economy, many Gen $Z$ students have older friends and family members who were a part of the above statistic. As educators, we need to help Gen $Z$ have realistic conversations about what it will take to be successful and expose Gen $\mathrm{Z}$ to careers in realistic ways through collaborative partnerships and internships that focus on applicable real-world skills.

\section{Fear of Missing Out}

Gen Z suffers from an intense fear of 'missing out'. In fact, $75 \%$ of Gen $\mathrm{Z}$ would be interested in a situation in which they could have multiple roles so that they do not 'miss out' on any potential career or learning opportunities (Stillman \& Stillman, 2017). To attend to this characteristic, educators should give constant feedback to help Gen Z stay on task and ensure that Gen Z does not feel as if they are missing out on anything. The constant feedback will also help Gen $Z$ deal with distractions. Other examples of how to maximize the effectiveness of this characteristic are to give multiple roles on projects and job assignments and break down the project assignments into manageable tasks with check-in periods.

\section{Weconomists}

Gen Z has grown up with shared economy companies like Uber and Airbnb. According to Stillman and Stillman's (2017) surveys, 93\% of Gen Z state that a company's effect on society affects their 
decision to work there. Gen $\mathrm{Z}$ will leverage the power of 'We' in their role as philanthropists, and Gen $\mathrm{Z}$ will expect to partner with employers that impact their community. By demonstrating how Gen $Z$ can use the skills learned in class to affect not only their employer but also their community, educators can expose students to the social responsibility aspect of business. As educators, we also have to help Gen $\mathrm{Z}$ focus on real results and effects, not just feel good gestures.

\section{Driven}

Gen $\mathrm{Z}$ is very competitive and may not collaborate as easily as Millennials. Stillman and Stillman (2017) mentioned that $88 \%$ of Gen Z state they would work longer hours and harder than their fellow Gen $\mathrm{Z}$ rock stars to reach their goals. Gen $\mathrm{Z}$ is a driven generation because they had parents who taught them that participation is not a real award, they have lived through a recession and experienced a world with a constant rate of change. As educators, we can help this generation be more effective in the workplace. By embracing and enjoying Gen Z's desire to win, educators can help balance their competitive drive with being team players. We can also provide coaches and mentors to guide them, so they do not make critical mistakes, and offer private, as well as shared assignments, so they learn to collaborate and work together.

Overall, these Gen $\mathrm{Z}$ characteristics shape the learning styles of accounting students in the classroom. By creating assignments within the service learning project that take advantage of the these six unique Gen Z characteristics, we were better able to engage students, increase the students' interest in accounting, better prepare the students for the accounting workforce, enhance the skillset required by future accounting employers, and instil the AICPA's core competencies.

\section{AICPA'S CORE COMPETENCY FRAMEWORK}

In 2002, the AICPA determined a certain skillset was needed by accounting students entering into the profession. Therefore, a group of educators developed the AICPA's core competency framework, which focused on three core areas of skill-based competencies required to be successful in the accounting profession. The three areas of concern for the profession consisted of functional, personal, and broad business perspective skills. The educators developing this framework wanted to ensure that students did not focus on just memorizing the material covered in the classroom.

The functional skills in the framework target risk analysis and the technical aspects of the profession (AICPA, 2002). Alternatively, the personal skills area focuses on developing individuals' leadership and communication skills, as well as their interactions with others. The broad business perspective core area aims to improve students' critical thinking and their acumen on branding themselves. By focusing on core areas that move students successfully from the academic setting to the professional environment, educators can adapt their curriculum to provide the best opportunity for their students.

In addition, the AICPA's core competency framework supports students' varied career paths, whether that includes public, private, government, or non-profit work environments. The ultimate goal of this framework was for students to develop lifelong learning skills to be adaptable and flexible within the accounting profession and provide value to the public.

\section{SERVICE LEARNING LINKED WITH ACCOUNTING}

After the onslaught of accounting scandals, institutions in the United States experienced a declining number of accounting majors. The early 21 st century was understandably a low time for the profession, and students were not exactly excited to go down an accounting path after the Enron debacle. Additionally, the AICPA's approach to developing core competencies proved that critical thinking and communication skills were needed in the profession (AICPA, 2002). Therefore, the addition of a service learning project corresponds well with aligning course material to these competency areas.

Previous research demonstrates that service learning gets students engaged and excited about the course (Albrecht \& Sacks, 2000). Additionally, service learning provides an opportunity to link course material with community service, as well as real-world experience in various sectors. This service 
learning project had students engaging with profit and non-profit companies throughout the semester, which allowed them to develop experience among those sectors. Most importantly, the project allowed interaction with faculty, students, and the community, which in turn developed those needed communication skills in the profession. Our institutional mission desires to teach individuals lifelong learning and to be enlightened citizens, and service learning provides an avenue to improve students' skillsets and give students an experience that allows them to understand the many needs of the community.

Overall, the benefits of service learning projects are linked to critical thinking, communication, hands-on learning, resume building, and research skills (Albrecht \& Sacks, 2000; Healy \& McCutcheon, 2008). These benefits allow students to develop lifelong learning skills, instead of just memorizing textbook content. By linking course material with service learning projects, accounting students gain experience in various sectors, develop the AICPA's core competencies demanded for the profession, and incorporate the unique characteristics of Gen $\mathrm{Z}$ students.

\section{UNIVERSITY MISSION}

The university is a private, Catholic institution that was established in the late 1800's. The university's mission focuses on educating men and women to become enlightened citizens through community service and the common good. Through this mission-driven institution, students are required to complete 45 hours of community service to qualify for graduation. Therefore, service learning projects in the classroom are strongly encouraged by the university's administration.

In cooperation with institution's service learning mission, non-profit organization was formed and established in 2010 focusing on tri-sector collaborations. The non-profit's research discovered the tremendous benefits that all three sectors (non-profit, for-profit, and education) can have when collaborating together. Additionally, this specific non-profit supports student organizations, while increasing students' exposure to local businesses and non-profit organizations.

\section{SERVICE LEARNING PROJECT}

Each semester accounting faculty collaborate to organize a service learning project that incorporates managerial and cost accounting elements. The university's School of Business and Administration partners with a local non-profit to support service project day, which is an opportunity for students and community members to engage in various service drives and philanthropic opportunities.

One semester, the service learning event raised money for at least 10 families at a homeless shelter built for women and children. With the help of accounting students and the members of the university's accounting club, the service project is a fun and rewarding way for students to experience community service. Additionally, students will gain knowledge of various skills with regard to managerial and cost accounting.

The project was divided into five parts over the course of the semester and utilized in both the cost and managerial accounting courses. The first part of the project involved a classroom race called the Amazing Accounting Race. Each group was required to complete different challenges, such as create a team name and poster, decide on the non-profit organization they were competing for, and answer some accounting questions. This activity was designed to be fun and collaborative, as a way to develop team unity and relationships among the group members. Team members were then asked to go throughout campus to take a team picture and gather a specific amount of money, which always helps start the fundraising aspect. Students always come back and are amazed at how easy it was to ask for money for their cause. The last leg of the race included defining the team's strategies for fundraising, which helped teams have a plan for the remaining semester.

The second part of the project included developing a mission, goals, and strategies for each group to achieve. Students within each group developed their method for raising money to meet their goal for the semester. Groups were guided on how much each group needed to raise to provide for the service project

116 Journal of Accounting and Finance Vol. 19(4) 2019 
event; however, groups could decide if they wanted to go above and beyond the required amount. This part of the project allows groups to begin developing relationships with other group members, as well as working on their communication and critical thinking skills to achieve the necessary amount donated.

The third part of the project gave students an opportunity for hands-on learning involving job order costing. Student groups were required to put together several bags of treats for the children of the homeless shelters. Students must use job order costing methods to determine the cost of each bag while including direct materials, direct labor, and overhead. This opportunity allows students to see how the cost of goods does not just involve materials, and carefully allocating overhead to products is crucial to assess the actual cost of the product accurately.

After students have determined the cost of treat bags, the project involves the thought process of strategic planning. The fourth part of the project had students creating a differential budget, as well as capital budgeting options. Students were given various alternatives and had to determine which alternative created the best differential income. Additionally, students must determine whether purchasing equipment, such as a snow-cone machine, would be a good investment instead of renting the machine each year. Each of these parts of the project was distributed after instruction in the classroom. By giving students a real-world scenario, understanding the process and importance of differential and capital budgeting becomes more clear and attainable.

The last part of the project involved a reflection of the group and its members. This part of the project allowed the instructors to update and improve the project continually. In addition, students improved their written communication skills by describing their experience with the project. Some of the feedback received from the reflection is discussed in the next section of the paper.

Before the reflection portion of the assignment was due, the community service and volunteer portion of the project occurred. The service project event occurred toward the end of the semester because the university hosts various women and children in need. The event was a chance for children to decorate cookies, face paint, and play various games with our student volunteers. Each semester, the activities change based on the time of year. For example, in the fall semester, children decorated a stocking and shopped for presents for their Mom at various stations throughout the event. In the spring semester, children were able to go on an Easter egg hunt. Each of these activities can be catered to the season or ability of the hosting institution. Additionally, more information can be provided to anyone interested in hosting this event at their institution.

On the day of the event, various non-profit organizations come to campus to spread awareness. An optional part of the project involves various social media challenges (See Table 1). The social media challenges are a way for students to earn additional community service hours, as stated that all our student s must earn 45 hours of community service before graduating. Additionally, some of the social media challenges help spread awareness of some the of the community's non-profit needs and help build relationships between the students and these organizations. This portion is optional, but students often get really excited about getting to utilize their phones to get on social media and post pictures of the event. 


\section{TABLE 1 \\ SOCIAL MEDIA CHALLENGES}

\begin{tabular}{|rl|}
\hline 1. & $\begin{array}{l}\text { Follow the designated non-profit organization on Facebook, Instagram and/or Snap } \\
\text { Chat }\end{array}$ \\
\hline 2. & Spell the non-profit organization with your body and include designated hashtags \\
\hline 3. & $\begin{array}{l}\text { Do a video and/or picture collage of the Social Media Event and post to your social } \\
\text { media, use the university geofilter, share with } 5 \text { friends }\end{array}$ \\
\hline 4. & Follow designated coffeehouse on Facebook, Instagram and/or Snap Chat \\
\hline 5. & Picture at designated coffeehouse and tag them on social media. \\
\hline 6. & $\begin{array}{l}\text { Picture with your service learning project and post to your social media include } \\
\text { designated hashtags. }\end{array}$ \\
\hline$* 0.2$ hours for each item completed \\
\hline
\end{tabular}

\section{FEEDBACK FROM PROJECT}

The reflection papers gave great feedback on skills and benefits developed or enhanced as a result of this project (See Table 2). The reflection papers along with some of the challenges faced in implementing the projects also gave great insight into how to make the projects better in the future.

\section{TABLE 2 REFLECTION FEEDBACK}

Below are excerpts from the reflection papers discussing the benefits and skills gained during this project:

'The accounting skills that we learned in class and that we were able to use on this project were, creating a mission/goal, completing a CVP Analysis, taking inventory, completing a differential analysis report, and lastly making a budget spreadsheet. Other than accounting skills we also used some soft skills during this project. We used skills such as leadership, communication, problemsolving, collaboration, teamwork, positive attitude, team management, self-confidence.'

'I feel that you learn more in this class through real-world application than you can in the classroom.' '...that experience gave me amazing operational accounting knowledge.'

'...real life examples have always helped me to learn better and give me something that I can reference later on.'

'We used leadership, communication, teamwork, collaboration, problem-solving, and adaptability to complete this project and have a successful turnout.'

'This event helped us get a better understanding of how to apply what we learned in class to the real world.'

'I enjoyed so much seeing [non-profit] organizations like......and learning about what they do and who they help. It was very Inspiring.'

'I learned that something so small, such as a shoe box with a few items in it, can really go a long way.'

'As a team leader, I learned how to effectively and efficiently manage a project, as well as how to adapt when an unanticipated challenge arises.'

'Teamwork and collaboration help to complete complex tasks.'

'I learned from this service project that there is power in numbers.'

'We also learned the principal of participation which taught us to work together towards a common goal and for a greater purpose for the community and self-growth.' 
'The Service Day ..... allowed each student to speak with each of the vendors to better understand their brand and how each of their respective companies manages and maintains their profits. As each brand described how their company enriches the community, it became clear to the students that the awareness they were bringing to each company was priceless.'

'This service event has taught me the skills and proper management of a real, non-profit organization.'

'Doing this project helped me a lot to understand more about all of the accounting process, and also to help the community. I will recommend for future accounting students to do this project; it will help them to understand things easier, and also to help.'

'This course gave me an entirely new set of skills in regards to production costs and how those costs are calculated and budgeted for. Our service learning project allowed me to practice problem-solving skills and take on a leadership role within in my group.'

To summarize the majority of the reflection papers, the skills mentioned were teamwork, humility, selflessness, collaboration, leadership, unity, participation, becoming more approachable, budgeting, courage to step outside of comfort zone, networking, and increasing their communication skills.

After several semesters of doing this project, the most common comment that we received in the student's reflection papers is that the students wished they knew the effect they were making on the community before the project started. Most of the students mentioned that they would have put in more effort and time on the project. As a result of this feedback, we now show video clips of past projects and have a representative from the non-profit organization come in to discuss the effect that the students have had and will have by successfully completing this project. By adding this component, the quality of the projects and the community impact has increased tremendously. Overall, based on the comments from the students, our goals of instilling the AICPA's core competencies and increasing the soft skills of our students were achieved.

\section{LIMITATIONS AND TIME CONSTRAINTS}

Although this project was very successful, there were a few limitations of the study. The research for this study included three principles of managerial accounting classes and one cost accounting class located at private, Catholic university for four separate semesters, with each semester lasting 16 weeks. Because of the small sample size, the results of our project should not be generalized to assess the benefits to all Gen Z students accurately. Another limitation is the population of the students. The institution is a faith-based university that has a 45-hour community service component that must be completed before graduation. This external requirement may have an effect on the students' willingness to participate and to be successful with a project that benefits the community. The majority of our students are from the southwest Texas region. This is a possible limitation because the information obtained may not be transferable to other areas and regions. Another limitation is the time frame in which the students were evaluated. The service learning project was evaluated over four semesters; this may not be enough time to fully evaluate the benefits of utilizing a tri-sector approach to engaging Gen $\mathrm{Z}$.

\section{Lessons Learned}

Although this project had some limitations, there were some very valuable lessons learned that could be applied to future classes to engage Gen $\mathrm{Z}$ students. The lessons learned can be divided into three categories; student preparation and empowerment, the service learning activity, and grading issues.

\section{Student Preparation \& Empowerment}

The project in and of itself is very time-consuming. In fact, if not careful, the project can take over and interfere with class teaching time. As accounting professors, our main job is to teach accounting theory and principles to ensure our students are well-educated accountants. With the addition of this project, we must also prepare and teach our students to effectively utilize their accounting skills in this 
project. To accomplish both objectives, we incorporated established dedicated training and teaching days along with separate application and project days in the syllabus.

We also found that student empowerment is also very important. To effectively empower the students, each student needs to have a specific job, established responsibilities, and clearly set expectations about their roles within the project. Most students rise to the task when they know up front what their responsibilities are and what is expected of them. By assigning specific tasks to the students throughout the semester and empowering them to figure out how to get it done, the students not only developed and increased their soft skills, but the students consistently amazed us with their ingenuity, creativity, and problem-solving skills.

\section{Service Learning Activity}

There were several lessons learned during the past semesters for achieving a successful service learning activity in the classroom. The first is establishing one's partnerships and creating one's assignments before the semester begins. The best way to do this is to utilize the university's resources, such as the Center for Service Learning, the community engagement departments, and the alumni association. The utilization of our university resources has proven to be the most beneficial component to the success of the project.

The second lesson learned is that the service learning projects work best with students working toward a common goal. Initially, we allowed each team of students to pick their own non-profit organization and create their own fundraising event. However, this proved to be very time consuming on the instructor because of all of the different variables involved in each project and the effect for each nonprofit organization was minimal. Then, the project morphed into the instructor selecting one non-profit organization for the semester, one large project was created, and each team concentrated on fundraising for the selected communal non-profit organization. This provided a more meaningful experience for the students, was less time consuming, and the effect to the community increased with all of the efforts and funds benefiting one organization.

Another lesson learned is the timing of the activity. The actual event should last no more than three hours, any longer than that, the students lose interest and so do the people who are attending one's event. The last issue is with funding the project. We are still working on trying to determine the best way to do this; it seems that the best way so far is a combination of student involvement with fundraising and outside sponsorships.

\section{Grading Issues}

Because this project is such a large component of the class, deciding how to weight this project is crucial to the success of this project. Based on our experience, over the last few semesters, the best weighting for a project of this magnitude should be $25 \%$ to $30 \%$ of the overall grade. This weighting is enough to get the students fully engaged in the project.

Another issue that one may encounter is how to divide the individual accountability grade with the team effort grade. Inevitably, there will be some students who will not be as involved as other students in making this project a success. Because of this, there must be an individual accountability component to the grade. Some semesters, we discovered a 'lone wolf' that would like to do the whole project himself/herself and not involve his/her other classmates, so also there also needs to be a team effort component to the grade. One of the best ways to tackle the grading issue is to make a percentage of the grade based on individual accountability and a percentage of the grade based on teamwork. The best percentage distribution for both teamwork and individual accountability seems to be $15 \%$ of the service learning grade. 


\section{CONCLUSION}

Overall, service learning based projects build a lifelong learning skillset for students through active learning techniques. A tri-sector approach to service learning is an empowering way to engage Gen $\mathrm{Z}$ accounting students because this method gives them exposure to multiple sectors, complements their unique characteristics, and develops the core competencies of the AICPA. This project not only increased the skillset of the students, which makes them more marketable to future employers, but also made a tremendous difference in the lives of the people we served during the service learning event.

This service learning project not only engaged the student in mastering managerial accounting topics that are often considered complex for some students but also instilled inspiration and creativity in the classroom. The students' utilized critical thinking skills to achieve their goals for the project, as well as develop an experience that could be listed on their resumes for future employment opportunities. Future research is needed to determine effective methods of fundraising for a service learning project.

\section{REFERENCES}

Accounting Education Change Commission. (1990). Objectives of education for accountants: Position statement number one. Issues in Accounting Education, 5, 307-312. Retrieved from http://aaajournals.org/loi/iace?code=aaan-site

Albrecht, W. S., \& Sacks, R. J. (2000). Accounting education: Charting the course through a perilous future. Accounting Education Series, 16. Sarasota, FL: American Accounting Association.

American Institute of Certified Public Accountants (2011). The CPA vision project. The Horizons 2025 Report, 11-45. Retrieved from https://www.aicpa.org/Research/ CPAHorizons2025/ DownloadableDocuments/cpa-horizons-report-web.pdf

American Institute of Certified Public Accountants (2002). Core competency framework. Retrieved from https://www.aicpa.org/InterestAreas/AccountingEducation/ Resources/Pages/CoreCompetency. aspx

Bonner, S. (1999). Choosing teaching methods based on learning objectives: An integrative framework. Issues in Accounting Education, 14, 11-39. doi: 10.2308/iace.1999.14.1.11

Bureau of Labor Statistics (2018). Databases, tables, and calculators by subject. Retrieved from https://data.bls.gov/timeseries/LNS14000000

Davidson, C. N. (2017). Active learning and the business of life: How the research process prepares students for the post-education experience. CHOICE: Current Reviews for Academic Libraries, 55, 158-159. Available in ProQuest.

Healy, M., \& McCutcheon, M. (2008). Engagement with active learning: Reflections on the experiences of Irish accounting students. The Irish Accounting Review, 15(1), 31-49. Retrieved from http://iafa.ie/accounting-finance-governance-review/

Stillman, D., \& Stillman, J. (2017). Gen Z @ work: How the next generation is transforming the workplace. New York, NY: Harper Collins.

Yardley-Matwiejczuk, K. M. (1997). Role play: Theory and practice. London, UK: Sage. 


\section{APPENDIX A: SERVICE LEARNING PROJECT}

\section{Service Learning Comprehensive Project- Principles II}

Your team is being hired by a non-profit to use your accounting skills to be a Brand Ambassador and create a service event. You will be working directly with the Chief Operating Officer of the nonprofit organization. Our goal will be to sponsor a least two parties for children at a specified homeless shelter.

1. Each team member will be responsible for completing at least one 'Spare-A-Dollar' sheet and forming a team. Each team must pay the team fee of $\$ 80.00$ per team $(\$ 20 /$ person).

2. This project will help support a local orphanage and elementary school. The money raised will be used to bring fun and joy to children by providing a party with inflatables and a game truck. We will also provide the food and a party bag for each child.

3. Students can earn up to 15 hours of community service by completing the community service challenges.

4. We will have activities and games throughout the semester for you to earn community service hours.

\section{Service Learning Project: Part I Mission/Goals}

Play the amazing race and complete the challenges that will help you complete part 1 of the service learning project. See below.

\section{Leg 1}

\section{The Amazing Accounting Race:}

Time: 10 minutes to complete this challenge

Create a Unique Team Name and Team Color - Make a sign with your team name and take a picture by the clock tower with your sign, and then email the picture to your professor.

\section{Leg 2}

Time: 10 minutes to complete this challenge

Decide as a team, which non-profit you will be playing for at the event- if you cannot decide in 10 minutes - you will be assessed a $\$ 2$ penalty, but make sure decide by the next class time.

\section{Leg 3}

Time: 10 minutes to complete this challenge

There are two accounting aspects to a business; financial and managerial. List the differences between financial and managerial accounting, including at least 3 differences, and turn into your professor.

\section{Leg 4}

Time: 20 minutes to complete this challenge

Your team will start to fundraise for the homeless families. As a team raise $\$ 10.00$ by collecting:

$5-1$ dollar bills, 12 quarters, 10 dimes, 15 nickels and 25 pennies.

*If this challenge is not complete with 20 minutes, the team will be assessed a $\$ 2$ penalty.

\section{Leg 5}

Time: 10 minutes

Mission/Goal/Strategy Challenge: We discussed the mission and goals for this event. Your job as a team is come up with 3 strategies on how your team is going to meet or exceed your team goal. 
Service Learning Project - Part 2 Cost-Volume-Profit Analysis

*Part 2 must be attempted on your own and brought to class

(1) Classify the costs below as: Product-Direct, Product-Indirect, or Period AND Variable cost, Fixed cost, or Mixed cost. Below are budgeted income statements at different team levels, use the information to answer the questions below:

\begin{tabular}{|l|l|l|l|l|l|}
\hline Number of Teams & $\mathbf{1 5}$ & $\mathbf{2 5}$ & $\mathbf{3 0}$ & $\begin{array}{l}\text { Product Direct, Product } \\
\text { Indirect or Period }\end{array}$ & $\begin{array}{l}\text { Fixed/ } \\
\text { Variable }\end{array}$ \\
\hline Sales & $\$ 1,500$ & $\$ 2,500$ & $\$ 3,000$ & & \\
\hline Cost of Goods Sold & & & & & \\
\hline Direct Materials & 75 & 125 & 150 & \\
\hline Direct Labor & 150 & 250 & 300 & \\
\hline Applied Overhead & 575 & 625 & 650 & \\
\hline $\begin{array}{l}\text { Gross Profit } \\
\text { Selling Expenses }\end{array}$ & $\$ 700$ & $\$ 1,500$ & $\$ 1,900$ & \\
\hline $\begin{array}{l}\text { Administrative } \\
\text { Expenses }\end{array}$ & 280 & 280 & 600 & & \\
\hline $\begin{array}{l}\text { Advertising } \\
\text { Expenses }\end{array}$ & 200 & 200 & 200 & & \\
\hline $\begin{array}{l}\text { Miscellaneous } \\
\text { Administrative }\end{array}$ & 100 & 100 & 100 & \\
Expenses
\end{tabular}

(2) Using the above data and the high/low method, answer the following questions:

\begin{tabular}{|c|c|}
\hline Units - Number of Teams & 15 \\
\hline Total Expenses & $(180)$ \\
\hline $\begin{array}{l}\text { a. Determin } \\
\text { b. Determin } \\
\text { c. What is th } \\
\text { d. Estimate }\end{array}$ & $\begin{array}{l}\text { variable cost per unit } \\
\text { fixed cost } \\
\text { ost equation? } \\
\text { otal cost for } 20 \text { teams }\end{array}$ \\
\hline
\end{tabular}

In addition to the above data, assume the company has the following sales. Answer the following questions:

\begin{tabular}{|l|l|l|l|}
\hline Number of Teams & $\mathbf{1 5}$ & $\mathbf{2 5}$ & $\mathbf{3 0}$ \\
\hline Sales & $\$ 1,500$ & $\$ 2,500$ & $\$ 3,000$ \\
\hline
\end{tabular}

e. What is the revenue generated per team?

f. What is the per unit contribution margin?

g. What is the contribution margin ratio?

h. Compute break-even point in dollars and in units (round to the next whole number) for each of the three scenarios. Then, choose a scenario for your team.

i. If organization wants to have net income of $\$ 100.00$ from this event, how many teams are needed?

j. If organization estimates 20 teams, determine the Margin of Safety in sales dollars. 
k. Perform a sensitivity analysis to determine how an increase in team revenue of $\$ 500$ would impact Net Income?

1. If the team revenue changed to $\$ 120$ per team, and all other expenses remained the same as calculated in your cost equation, what is the new break-even in units?

$\mathrm{m}$. If the variable costs changed to $\$ 50$ per team (the fix costs remained the same as in your cost equation, and team revenue remained at $\$ 100$ per team), what is the new break-even in units?

n. If the fixed costs changed to $\$ 980$, (variable expenses remained the same as in your cost equation, and sales price remained at $\$ 100$ per team), what is the new breakeven in units?

\section{Service Learning Project - Part 3 Inventory}

Set up the 3 inventory t-accounts and placeholders and complete the job order costing service learning project. You are going to put together a party bag for event for the children.

a. Each member of the group will utilize job order costing and determine the cost of their team's party bag. Your team will need to assemble one party bag.

- Labor charge is $\$ 1.25$ per cup

- Total material purchased is 120.00 for the entire project Material needed for the job:

- Bag Assembly:

1 bag - .10 each

1 large snack - .20 per snack

1 Fruit snack - .20 per snack

$1 \mathrm{M} \& \mathrm{M}$ package -.20 per pack

5 pieces of small candy - .05 cents egg

Card -.20 cents per card

Ribbon - .05 cents per piece of ribbon

b. Template data:

Cost Flow Sheet -

- Assume Beginning WIP and Beginning Materials are zero and ending WIP is zero

- Assume Beginning Finished Goods is 1.20, and ending Finished Goods are zero.

- The total estimated overhead is $\$ 200$. You are going to estimate overhead using, the traditional approach. You are going to allocate overhead based on direct labor dollars - the total estimated direct labor dollars for the project is $\$ 400$.

- What is the applied overhead rate?

- Apply the rate:

- What was the total labor charges for your team $?$

- What is the amount of applied overhead for your team?

*Hint: Take the applied rate* total labor charges $=$ applied $\mathrm{OH}$

- If Actual Overhead is $\$ 2.20$, are you under or overapplied and by how much? 
Service Learning - Part 4 Differential Analysis (at home first)

Complete the Differential Analysis for your business.

We are planning a party at some area orphanages and homeless shelters. The project is operating at a loss, should the organization discontinue this project?

\begin{tabular}{lr} 
Sales & $\$ 2,400$ \\
COGS & 2,000 \\
\hline Gross Profit & 400 \\
Operating Expenses & 500, \\
\hline Loss from Operations & $(\$ 100)$
\end{tabular}

*The company estimates that $20 \%$ of COGS are fixed and $60 \%$ of operating expenses are variable.

Should the company discontinue this project? Why or Why Not?

(1) Complete the Capital Budgeting Analysis:

The organization is looking into investing into an inflatable obstacle course. The inflatable obstacle course has an initial investment of $\$ 4,000$. The inflatable obstacle course will last for 8 years. If the obstacle course is purchased, the organization will save $\$ 500$ every year for 8 years because they will not have to rent the obstacle course. The discount rate is $8 \%$.

a. Is this an example of annuity or a present value of 1 ?

b. Should we purchase the obstacle course?

c. If we had another project, a popcorn machine, that had a profitability index of 1.5 , and could only choose one project, which project should we choose and why?

\section{Service Learning - Part 5 Reflection}

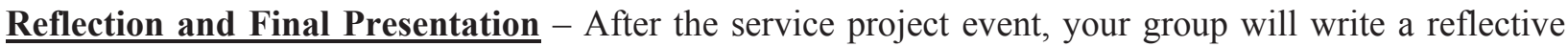
paper and review your team strategies and goals. These are some of the talking points to use in your paper:

- Did your team meet your team goals?

- What accounting skills learned in this class relate to the service learning event?

- What soft skills (leadership, communication, teamwork, collaboration, problemsolving, adaptability, customer relationships) learned in this class relate to the service learning event?

- Based on what you learned from the project, why are donations so important to the effectiveness of non-profit organizations?

- Each team member is to write at least one sentence regarding what they learned from the service learning event.

- Each team member is to list exactly what they did on the project.

- What can make this event better next semester? 


\section{Grading Rubric}

\begin{tabular}{|l|l|}
\hline $\begin{array}{l}\text { Answering the Questions, bringing materials and } \\
\text { completing the template }\end{array}$ & 50 points \\
\hline Group Reflection Project & 20 Points \\
\hline $\begin{array}{l}\text { Meeting individual portion of the team goal and } \\
\text { your individual contribution to the overall projects } \\
\text { Each line over } 25 \text { lines gets an extra bonus point - } \\
\text { up to 5 extra points }\end{array}$ & 20 Points \\
\hline \begin{tabular}{c} 
Team Business Goals ( 5, 10, or 15 Points) \\
\hline Meet over half the goal
\end{tabular} & Goal \\
\hline Meet the goal & 5 Points \\
\hline Exceed the goal by earning a profit & 10 Points \\
\hline
\end{tabular}

*** If you do not attempt the problems on your own and bring it to class completed to work in your group, you will be docked two letter grades from the group*** 